\title{
Rapid assessment of iron in blood plasma and serum by
}

\section{spectrophotometry with cloud-point extraction [version 1;}

\section{peer review: 2 approved]}

\section{Tatyana Samarina, Mikhail Proskurnin}

Chemistry Department, Agilent Technologies Partner Laboratory - Analytical Centre, M.V. Lomonosov Moscow State University, Moscow, 119991, Russian Federation

V1 First published: 25 Aug 2015, 4:623

https://doi.org/10.12688/f1000research.6716.1

Latest published: 25 Aug 2015, 4:623

https://doi.org/10.12688/f1000research.6716.1

\section{Abstract}

Rapid photometric assessment of iron in blood plasma and serum by a simple procedure after the extraction of iron(II) complex with 1nitroso-2-naphthol in the micellar phase of a nonionic surfactant at the cloud point upon heating ( $\mathrm{pH}$ range is 4.5-6.3) is proposed. The procedure trueness was verified using a standard reference protocol using bathophenanthroline. The advantages of the procedure are higher sensitivity than the reference protocol: the limit of detection is $0.03 \mu \mathrm{g} / \mathrm{mL}$, the limit of quantitation is $0.1 \mu \mathrm{g} / \mathrm{mL}$, the determination range is $0.1-2.8 \mu \mathrm{g} / \mathrm{mL}$ (RSD 0.02-0.10). Copper does not interfere with the iron assessment.

\section{Keywords}

iron assessment, plasma, serum, cloud-point extraction, spectrophotometry

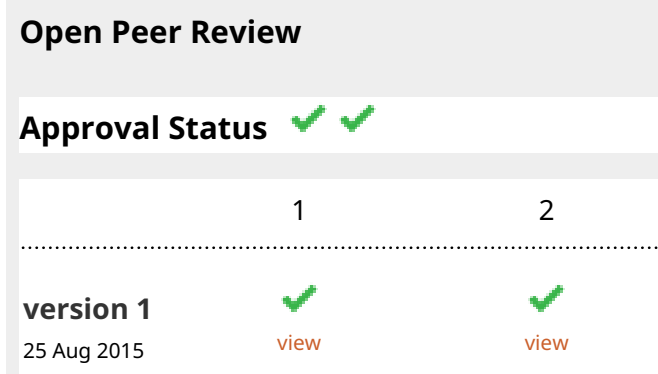

1. Jean-Paul Canselier, University of Toulouse,

Toulouse, France

2. Massoud Kaykhaii, University of Sistan and Baluchestan, Zahedan, Iran

Any reports and responses or comments on the article can be found at the end of the article.

Corresponding author: Mikhail Proskurnin (proskurnin@gmail.com)

Competing interests: The authors declare that they have no competing interests.

Grant information: The work is supported by The Russian Science Foundation, grant no. 14-23-00012 (MP).

The funders had no role in study design, data collection and analysis, decision to publish, or preparation of the manuscript.

Copyright: ( $) 2015$ Samarina T and Proskurnin M. This is an open access article distributed under the terms of the Creative Commons Attribution License, which permits unrestricted use, distribution, and reproduction in any medium, provided the original work is properly cited. Data associated with the article are available under the terms of the Creative Commons Zero "No rights reserved" data waiver (CCO 1.0 Public domain dedication).

How to cite this article: Samarina T and Proskurnin M. Rapid assessment of iron in blood plasma and serum by spectrophotometry with cloud-point extraction [version 1; peer review: 2 approved] F1000Research 2015, 4:623

https://doi.org/10.12688/f1000research.6716.1

First published: 25 Aug 2015, 4:623 https://doi.org/10.12688/f1000research.6716.1 


\section{Introduction}

Iron level in blood plasma is affected by many physiological and pathological conditions ${ }^{1}$. Plasma iron is determined in diagnosing hemochromatosis ${ }^{2,3}$, acute iron poisoning ${ }^{4}$, active cirrhosis ${ }^{5}$, or hepatitis ${ }^{6}$, which lead to increased levels of transferrin, an iron(III)-binding glycoprotein that transports iron in the human body $^{7}$. Only $0.1 \%$ of the total iron is present in the blood plasma ${ }^{2}$, thus its assessment should be rather sensitive, precise, and rapid.

Iron in plasma/serum is determined by spectrophotometry or atomic-absorption spectroscopy ${ }^{8,9}$ after the recovery of transferrinbound iron(III) from acidic solutions using chelatants or detergents ${ }^{10}$. Highly sensitive and specific though labour-extensive radioisotope ${ }^{11}$ and immunological ${ }^{12}$ assays for iron in blood plasma are seldom used due to the need for special equipment and expensive reagents. Spectrophotometric methods are most frequent in clinical practice and based on the formation of iron chelates with bathophenanthroline recommended as a reference method ${ }^{13-15}$ or its sulfonated analogue $\mathrm{e}^{14,16}$, ferrozine ${ }^{17}$, Ferene $\mathrm{S}^{18-20}$, or Chromazurol $\mathrm{S}^{21}$. However, they are not always sensitive and (e.g. ferrozine) result in overestimation compared to bathophenanthroline ${ }^{22}$.

We report rapid photometric determination of iron in blood plasma and serum by a simple procedure after the extraction of iron(II) complex with 1-nitroso-2-naphthol into the micellar phase of a nonionic surfactant at the cloud point upon heating.

\section{Methods}

An Agilent Cary 60 spectrophotometer (USA; optical path length, $1 \mathrm{~cm}$ ) and an inoLab $\mathrm{pH}$ Level $1 \mathrm{pH}$-meter (Germany) with a glass $\mathrm{pH}$-selective electrode (precision $\pm 5 \%$ ) were used. Solutions were mixed with a Biosan MMS 3000 automixer with a micro-stirrer. Mass-spectrometry measurements were performed on a quadrupole Agilent 7500c ICP-MS (Germany) in a time-resolved analysis mode. The sample introduction system consisted of a robust Babbington nebulizer with a Scott spray chamber (Agilent Technologies) cooled by a Peltier element $\left(2^{\circ} \mathrm{C}\right)$. The data were acquired and processed with ICP-MS ChemStation (version G1834B) software (Agilent Technologies).

A GSO 7765-2000 Russian certified reference sample of Fe(III) (1.00 mg/mL in $0.1 \mathrm{M} \mathrm{HCl}$ ) was used for calibration. 1-nitroso-2naphthol (Reakhim, Russia) purified as in 23, ascorbic acid (Fluka, China), neonol (AF-neonol 9-12, Elarum, Russia), sodium and ammonium acetates, $\mathrm{HCl}$, trichloroacetic acid (all from KhimMed, Russia), bathophenanthroline (ReaKhim, Russia), and ethanol (Ferien, Russia) were used.
Buffer solutions ( $\mathrm{pH} 4$ ) were prepared by adding the necessary amount of a $1 \mathrm{M}$ sodium acetate solution to $0.1 \mathrm{M}$ hydrochloric acid. Chemically pure chloroform (KomponentReaktive, Russia) pre-washed with water from hydrochloric acid was used as a micellar phase diluent.

Blood samples were provided by 2 healthy volunteers. All tests were made in 3 replicates. To obtain native serum, a sample was put in a clean glass test tube and left for $1 \mathrm{~h}$ at room temperature to form a clot. The clot was separated from the walls with a glass tip and the sample was centrifuged for $15 \mathrm{~min}$ at $1500 \mathrm{rpm}$. The resulting serum was transferred into a clean test tube. For the decomposition of the iron(III) complex with transferrin, $0.5 \mathrm{ml}$ of serum/plasma in a glass test tube was mixed with $1 \mathrm{ml}$ of $2 \mathrm{M} \mathrm{HCl}$, next, $1 \mathrm{ml}$ of fresh $2.5 \%$ ascorbic acid solution was added. The sample was diluted to $5 \mathrm{ml}$ and mixed thoroughly.

\section{Procedure with cloud-point extraction}

A $1 \mathrm{ml}$ portion of the test or a calibration solution is mixed with $1 \mathrm{ml}$ of a $0.001 \mathrm{M}$ reagent solution in $5 \%$ neonol, $0.5 \mathrm{ml}$ of $1 \mathrm{M}$ sodium acetate, and $8.5 \mathrm{ml}$ of $5 \%$ neonol in a glass test tube. In the blank, $1 \mathrm{ml}$ of distilled water was added instead of plasma/serum. Solutions were stirred in a boiling water bath for $15 \mathrm{~min}$. Blood proteins denaturise and form a viscous white precipitate in the upper phase. Next, test tubes are cooled for $1 \mathrm{~min}$ in a cold-water stream, and the upper phase is removed by decanting. The lower, micellar, phase $(0.6 \mathrm{~mL})$ is diluted to $1.5 \mathrm{ml}$ of chloroform and absorbance is measured at $715 \mathrm{~nm}$ against the blank.

\section{Reference procedure with bathophenanthroline}

$0.7 \mathrm{ml}$ of the test sample was mixed with $0.1 \mathrm{ml}$ of $1 \%$ ascorbic acid, $0.35 \mathrm{ml}$ of $1 \mathrm{M} \mathrm{HCl}$, and after stirring, with $0.2 \mathrm{ml}$ of $20 \%$ trichloroacetic acid and centrifuged at $1500 \mathrm{rpm}$. A 0.7-ml supernatant of the reaction mixture is transferred into a test tube, $0.6 \mathrm{ml}$ of saturated ammonium acetate and $0.7 \mathrm{ml}$ of a bathophenanthroline solution in ethanol are added. After $1 \mathrm{~min}$, absorbance is measured at $536 \mathrm{~nm}$ against the blank.

\section{Results and discussion}

The conditions for iron preconcentration with 1-nitroso-2-naphthol into a neonol micellar phase in the cloud point were selected as reported elsewhere ${ }^{24}$. The iron recovery is $98 \pm 2 \%$. The optimum $\mathrm{pH}$ range is $4.5-6.3$; the limit of detection is $0.03 \mu \mathrm{g} / \mathrm{mL}$, the determination range is $0.1-2.8 \mu \mathrm{g} / \mathrm{mL}$ ( $\mathrm{RSD} 0.02-0.10$ ). The verification of the procedure using the reference protocol (bathophenanthroline) and an independent method (ICP-MS, isotope ${ }^{54} \mathrm{Fe}$ ) shows insignificantly different results (Table 1 ).

Table 1. The results of extraction-photometric determination of iron(II) in biological fluids (concentration of 1-nitroso-2-naphthol, $1 \times 10^{-4} \mathrm{M}, \mathrm{pH} 4.8$, $t=15 \mathrm{~min}, I=1.0 \mathrm{~cm}, n=3, P=0.95)$.

\begin{tabular}{|l|l|l|l|l|}
\hline Sample & $\begin{array}{l}\text { Blood plasma } \\
(\boldsymbol{\mu g} / \mathbf{m L})\end{array}$ & RSD & $\begin{array}{l}\text { Blood serum } \\
(\boldsymbol{\mu g} / \mathbf{m L})\end{array}$ & RSD \\
\hline CPE procedure & $1.71 \pm 0.24$ & 0.06 & $1.32 \pm 0.17$ & 0.05 \\
\hline Reference method & $1.74 \pm 0.16^{\mathrm{a}}$ & $0.05^{\mathrm{a}}$ & $1.34 \pm 0.29^{\mathrm{b}}$ & $0.09^{\mathrm{b}}$ \\
\hline $\begin{array}{l}\text { a ICP-MS } \\
\text { beference protocol with bathophenanthroline }\end{array}$ & & & & \\
\hline
\end{tabular}


The own colour of the reagent does not affect the blank. It is noteworthy that copper(II), existing in significant quantities in plasma and serum ${ }^{25}$, does not interfere with the determination as the absorbance maximum of copper complex with nitroso-naphthols lies at $430-490 \mathrm{~nm}$. This avoids using toxic and corrosive thioglycolic acid as a masking reagent. In addition, sample procedure provides the denaturisation of proteins and their removal at the stage of phase separation. Finally, the advantage of the proposed procedure over the bathophenanthroline protocol is much higher sensitivity: while the reference protocol assumes the determination at the boundary of the spectrophotometer working range, the results for our procedure correspond to its middle. Moreover, the separation does not exceed $15 \mathrm{~min}$, which is promising for the development of rapid assessment protocols. It is also noteworthy that the extraction occurs under rather soft conditions, and the $\mathrm{pH}$ interval of complex formation in the nonionic surfactant is rather wide $(c a .1 \mathrm{pH}$ both in acidic and alkaline ranges).

\section{Dataset 1. Raw dataset for Samarina et al., 2015 'Rapid assessment of iron in blood plasma and serum by spectrophotometry with cloud-point extraction'}

http://dx.doi.org/10.5256/f1000research.6716.d100757

Blood samples were provided by 2 healthy volunteers. All tests were made in 3 replicates.

\section{Data availability}

F1000Research: Dataset 1. Raw dataset for Samarina et al., 2015 'Rapid assessment of iron in blood plasma and serum by spectrophotometry with cloud-point extraction', 10.5256/f1000research.6716.d10075726

\section{Author contributions}

MP and TS conceived the study and carried out the research. TS designed the experiments. TS and MP prepared the first draft of the manuscript. All authors have seen and agreed to the final content of the manuscript.

\section{Competing interests}

The authors declare that they have no competing interests.

\section{Grant information}

The work is supported by The Russian Science Foundation, grant no. 14-23-00012 (MP).

I confirm that the funders had no role in study design, data collection and analysis, decision to publish, or preparation of the manuscript.

\section{Acknowledgements}

We are grateful to Agilent Technologies - Russia and its CEO, Dr. Konstantin Evdokimov, for Agilent equipment used in this study. Samples of blood plasma courtesy of Dr. I. F. Seregina (M.V. Lomonosov Moscow State University).
1. Andrews NC: Iron metabolism: iron deficiency and iron overload. Annu Rev Genomics Hum Genet. 2000; 1: 75-98. PubMed Abstract | Publisher Full Text

2. Hider RC, Kong X: Iron: effect of overload and deficiency. In: A. Sigel, H. Sigel, RKO. Sigel (Eds.) Interrelations between Essential Metal lons and Human Diseases. Met lons Life Sci. Springer, Netherlands. 2013; 13: 229-294. PubMed Abstract | Publisher Full Text

3. Kowdley KV: Iron, hemochromatosis, and hepatocellular carcinoma Gastroenterology. 2004; 127(5 Suppl 1): S79-S86. PubMed Abstract | Publisher Full Text

4. Banner W Jr, Tong TG: Iron poisoning. Pediatr Clin North Am. 1986; 33(2): 393-409. PubMed Abstract

5. Stål P: Iron as a hepatotoxin. Dig Dis. 1995; 13(4): 205-222. PubMed Abstract

6. Silva IS, Perez RM, Oliveira PV, et al.: Iron overload in patients with chronic hepatitis $\mathrm{C}$ virus infection: clinical and histological study. J Gastroenterol Hepatol. 2005; 20(2): 243-248. PubMed Abstract | Publisher Full Text

7. Wheby MS, Umpierre G: Effect of Transferrin Saturation on Iron Absorption in Man. N Engl J Med. 1964; 271: 1391-1395. PubMed Abstract | Publisher Full Text

8. Jittangprasert $P$, Wilairat $P$, Pootrakul $P$ : Comparison of colorimetry and electrothermal atomic absorption spectroscopy for the quantification of nontransferrin bound iron in human sera. Southeast Asian J Trop Med Public Health 2004; 35(4): 1039-1044. PubMed Abstract

9. Favier A, Maljournal B, Decoux G, et al:: Microanalysis of serum iron by atomatic absorption spectrophotometry in a graphite oven: improvement and evaluation of this method. Ann Biol Clin (Paris). 1983; 41(1): 45-50. PubMed Abstract

10. Koshiishi I, Mamura Y, Liu J, et al.: Evaluation of an acidic deproteinization for the measurement of ascorbate and dehydroascorbate in plasma samples. Clin Chem. 1998; 44(4): 863-868. PubMed Abstract
11. Fraser CG, Petersen PH, Ricos C, et al:: Proposed quality specifications for the imprecision and inaccuracy of analytical systems for clinical chemistry. Eur Clin Chem Clin Biochem. 1992; 30(5): 311-317. PubMed Abstract | Publisher Full Text

12. Levy AL, Vitacca P: Direct Determination and Binding Capacity of Serum Iron. Clin Chem. 1961; 7(3): 241-248. Reference Source

13. Lewis SM: International Committee for Standardization in Hematology: proposed recommendations for measurement of serum iron in human blood. Am J Clin Pathol. 1971; 56(4): 543-545. PubMed Abstract

14. Recommendations for measurement of serum iron in human blood. $\mathrm{Br}$ Haematol. 1978; 38(2): 291-294. PubMed Abstract | Publisher Full Text

15. Derman DP, Green A, Bothwell TH, et al.: A systematic evaluation of bathophenanthroline, ferrozine and ferene in an ICSH-based method for the measurement of serum iron. Ann Clin Biochem. 1989; 26(Pt 2): 144-147. PubMed Abstract | Publisher Full Text

16. Thomas B, Gautam A, Prasad BR, et al:: Evaluation of micronutrient (zinc, copper and iron) levels in periodontitis patients with and without diabetes mellitus type 2: a biochemical study. Indian J Dent Res. 2013; 24(4): 468-73. PubMed Abstract | Publisher Full Text

17. Carter P: Spectrophotometric determination of serum iron at the submicrogram level with a new reagent (ferrozine). Anal Biochem. 1971; 40(2) 450-458. PubMed Abstract | Publisher Full Text

18. Pieroni L, Khalil L, Charlotte F, et al.: Comparison of bathophenanthroline sulfonate and ferene as chromogens in colorimetric measurement of low hepatic iron concentration. Clin Chem. 2001; 47(11): 2059-2061. PubMed Abstract

19. Revised recommendations for the measurements of the serum iron in human blood. Iron Panel of the International Committee for Standardization in Haematology. Br J Haematol. 1990; 75(4): 615-616. PubMed Abstract | Publisher Full Text 
20. Charlier C, Plomteux G, Vernet M, et al:: Modification of the selected method for the determination of serum iron. Substitution of bathophenanthroline by ferene S. Ann Biol Clin (Paris). 1992; 50(3): 191-202.

PubMed Abstract

21. Brivio G, Brega A, Torelli G: Determination of iron and iron-binding capacity in serum without blank sample. Ric Clin Lab. 1986; 16(4): 523-532. PubMed Abstract

22. Lauber K: Determination of serum iron; a comparison of two methods: Teepol/ dithionite/bathophenanthroline versus guanidine/ascorbic acid/Ferrozine (author's transI). J Clin Chem Clin Biochem. 1980; 18(2): 147-148. PubMed Abstract

23. Umland $\mathrm{F}$, Janssen $\mathrm{A}$, Thierig $\mathrm{D}$, et al.: Theorie und pratische anwendung von komplexbildnern. Akademische Verlagsgesellschaft Frankfurt am Main. 1971. Reference Source
24. Samarina TO, Ivanov VM, Figurovskaya VN: Optical and chromaticity parameters of transition metal complexes with 1-nitroso-2-naphthol-3,6-disulfonic acid in the presence of surfactants. J Anal Chem (Russ.). 2012; 67(4): 321-329.

Publisher Full Text

25. Yamashita S, Abe A, Noma A: Sensitive, direct procedures for simultaneous determinations of iron and copper in serum, with use of 2-(5-nitro-2pyridylazo)-5-(N-propyl-N-sulfopropylamino)phenol (nitro-PAPS) as ligand. Clin Chem. 1992; 38(7): 1373-1375.

PubMed Abstract

26. Samarina T, Proskurnin M: Dataset 1 in: Rapid assessment of iron in blood plasma and serum by spectrophotometry with cloud-point extraction. F1000Research. 2015 .

Data Source 


\section{Open Peer Review}

\section{Current Peer Review Status:}

\section{Version 1}

Reviewer Report 09 May 2016

https://doi.org/10.5256/f1000research.7213.r13727

(C) 2016 Kaykhaii M. This is an open access peer review report distributed under the terms of the Creative Commons Attribution License, which permits unrestricted use, distribution, and reproduction in any medium, provided the original work is properly cited.

\section{Massoud Kaykhaii}

Department of Chemistry, Faculty of Sciences, University of Sistan and Baluchestan, Zahedan, Iran

This paper describes a method for the determination of iron in blood serum and plasma by a simple photometric procedure based on the cloud point extraction of a complex formed between ferrous ions and 1-nitroso-2-naphthol. Since spectrophotometric instrumentations own merits of simplicity, cheapness, portability and so on, this makes the paper interesting.

The authors claim that this is a "rapid" assessment of iron; therefore, it is better that the total analysis time be specified. Also it's better to have the complex formation reaction between Iron (II) ions and the ligand. Moreover, I prefer to see a table in which a comparison between the proposed method with other spectrophotometry methods for the determination of Fe(II) in blood samples is included.

Competing Interests: No competing interests were disclosed.

I confirm that I have read this submission and believe that I have an appropriate level of expertise to confirm that it is of an acceptable scientific standard.

Reviewer Report 22 February 2016

https://doi.org/10.5256/f1000research.7213.r12443

(C) 2016 Canselier J. This is an open access peer review report distributed under the terms of the Creative Commons Attribution License, which permits unrestricted use, distribution, and reproduction in any medium, provided the original work is properly cited.

\section{Jean-Paul Canselier}

Laboratory of Chemical Engineering, INPT/ENSIACET, University of Toulouse, Toulouse, France

The authors should better specify the nature of the surfactant 'Neonol AF 9-12', that is a 
polyethoxylated nonylphenol with ca. 12 ethylene oxide units, and the conditions of the cloud point extraction. In fact, the surfactant cloud point is rather high (ca. $86^{\circ} \mathrm{C}$ ?) and cooling down must be very sudden (quenching). Also, be sure that the conditions for iron preconcentration into the Neonol micellar phase are reported in ref.24.

In addition, the paper deals with complexation with 1-nitroso-2 naphtol whereas ref.24 describes complexation with 1-nitroso-2 naphtol-3,6-disulfonic acid.

The past tense ('was, were' instead of' is, are') should be used in the § 'Procedure with cloud point extraction' and 'Reference procedure with bathophenanthroline'.

Competing Interests: No competing interests were disclosed.

I confirm that I have read this submission and believe that I have an appropriate level of expertise to confirm that it is of an acceptable scientific standard.

\section{Comments on this article}

\section{Version 1}

Author Response 11 Nov 2015

Mikhail Proskurnin, Agilent Technologies Partner Laboratory - Analytical Centre, M.V. Lomonosov Moscow State University, Moscow, Russian Federation

Dear Dr. Filik,

Thank you very much for your comment on our paper. I still believe you a bit fast to conclude that the method published in this paper is the same in terms of the same reagent (NN) and general approach

1. Different material: The paper you cite deals with the determination of metals in steel, not in blood with complex protein-based matrix, which moves us from inorganic to organic sample preparation completely changes the process.

2. Different iron species: The paper you cite deals with iron(III) chelate of NN, and the authors work at $\mathrm{pH} 1$, while we succeeded in moving to weakly acidic media.

3. Different reagent preparation approach: The reagent in the cited paper deals with using 100 $\mathrm{mL}$ of dimethyl ether for NN preparation, while we use solubilization of the reagent using neonol, which is significantly different approach.

Probably, you are correct that this paper should be cited in the subsequent versions of the paper.

Competing Interests: No competing interests were disclosed. 
Reader Comment 19 Oct 2015

Hayati Filik, Istanbul University, Turkey

Please see this article: Yun J, Choi H: Micellar colorimetric determination of iron, cobalt, nickel and copper using 1-nitroso-2-naphthol. Talanta. 2000; 52(5): 893-902.

Similar or same method was previously published.

Competing Interests: No competing interests

The benefits of publishing with F1000Research:

- Your article is published within days, with no editorial bias

- You can publish traditional articles, null/negative results, case reports, data notes and more

- The peer review process is transparent and collaborative

- Your article is indexed in PubMed after passing peer review

- Dedicated customer support at every stage

For pre-submission enquiries, contact research@f1000.com 